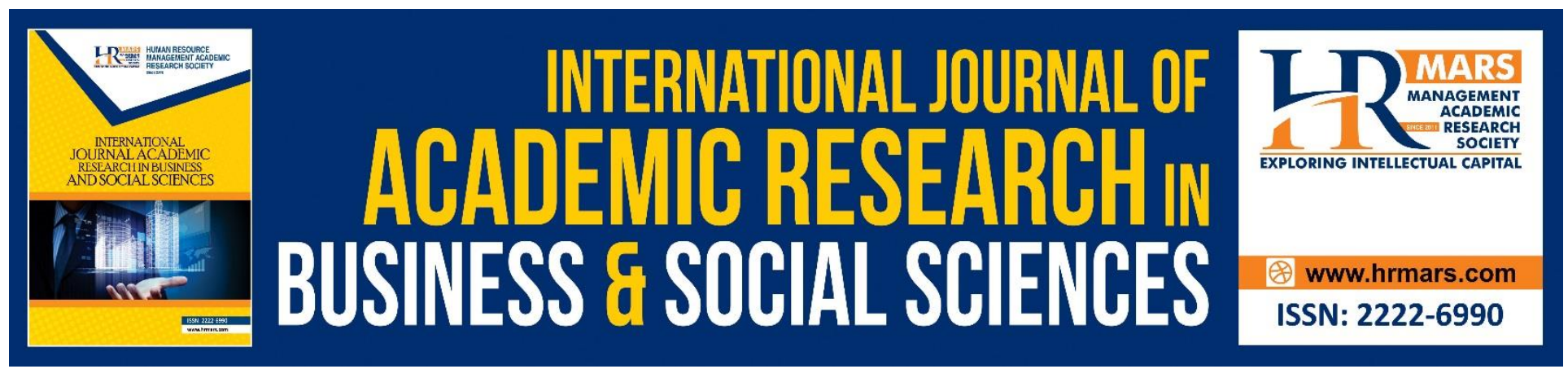

\title{
Approach of Sunnah Practice in Perlis, Malaysia
}

Mohamad Abdul Kadir Sahak \& Basri Ibrahim

To Link this Article: http://dx.doi.org/10.6007/IJARBSS/v10-i9/7885

DOI:10.6007/IJARBSS/v10-i9/7885

Received: 09 June 2020, Revised: 11 July 2020, Accepted: 16 August 2020

Published Online: 26 September 2020

In-Text Citation: (Sahak, \& Ibrahim, 2020)

To Cite this Article: Sahak, M. A. K., \& Ibrahim, B. (2020). Approach of Sunnah Practice In Perlis, Malaysia. International Journal of Academic Research in Business and Social Sciences. 10(9), 921-933.

\section{Copyright: (C) 2020 The Author(s)}

Published by Human Resource Management Academic Research Society (www.hrmars.com)

This article is published under the Creative Commons Attribution (CC BY 4.0) license. Anyone may reproduce, distribute, translate and create derivative works of this article (for both commercial and non-commercial purposes), subject to full attribution to the original publication and authors. The full terms of this license may be seen

at: $\underline{\text { http://creativecommons.org/licences/by/4.0/legalcode }}$

Vol. 10, No. 9, 2020, Pg. 921 - 933

http://hrmars.com/index.php/pages/detail/IJARBSS

JOURNAL HOMEPAGE

Full Terms \& Conditions of access and use can be found at http://hrmars.com/index.php/pages/detail/publication-ethics 


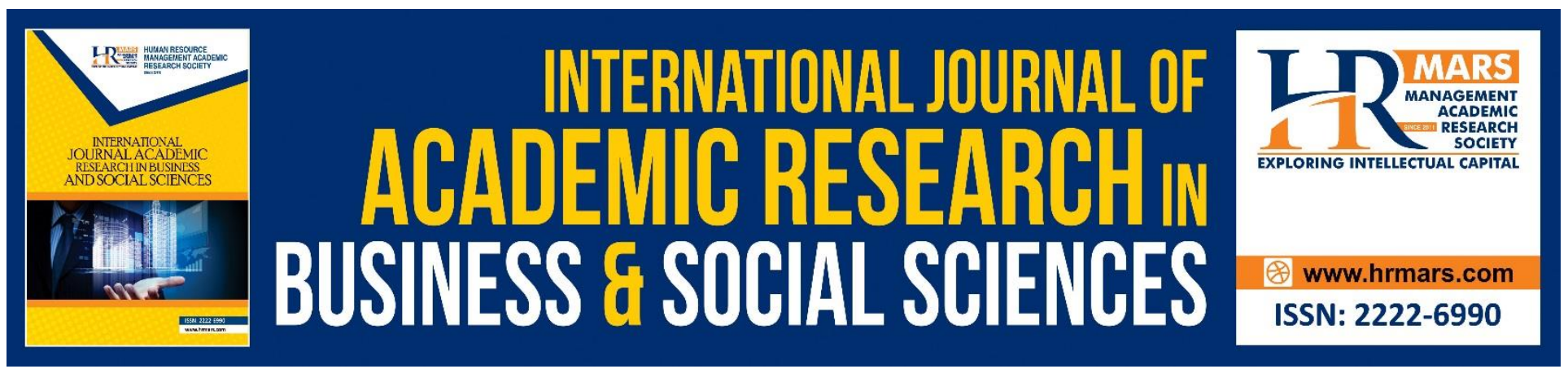

\title{
Approach of Sunnah Practice in Perlis, Malaysia
}

\author{
Mohamad Abdul Kadir Sahak ${ }^{1} \&$ Basri Ibrahim² \\ ${ }^{1}$ University Islam Malaysia, Cyberjaya, Malaysia, ${ }^{2}$ University Islam Malaysia, Cyberjaya, Malaysia/ \\ Faculty of Islamic Contemporary Studies, University Sultan Zainal Abidin, Terengganu, Malaysia. \\ Email: kadiry2k@gmail.com
}

\begin{abstract}
Sunnah or al-Sunnah is a thing familiar in Muslim community around the world and Muslim community in Malaysia in particularly. Sunnah is the explainer of al-Quran al-Karim. Understanding of al-Quran would not be completed except by referring to al-Sunnah. Muslim community have agreed on this matter. All states in Malaysia practice the belief of Ahl al-Sunnah Wa al-Jamaah. Only the state of Perlis is more famous with Sunnah compared to others until nicknamed as "Darus Sunnah". Many factors are contributing to this nickname, among them is the approach taken by religious figures and political figures in Perlis. In fact, the most main and biggest factor is the role of DYMM His Highness King of Perlis and DYTM His Highness Raja Muda of Perlis in sparking sunnah discourses until they become the main word of mouth among community. In consequence of that, this writing aims to explain on approach of sunnah practice practised in the state of Perlis suiting its nickname darul sunnah. Method implemented in this writing was based on qualitative method. Data were collected from library research and focused on perception of al-Quran, al-Sunnah, famous books regarding with sunnah, official documents of Perlis state government and files from Mufti Department of Perlis. This study found that Perlis is a very strict state in defending, disseminating and fighting for sunnah in daily practices. All practices related to Islamic religion should in advance be ensured to have strong reference from religious sources as agreed by scholars of Ahl al-Sunnah Wa al-Jamaah. Practice lacking of reference or practice based on weak reference or argument will not have place in the state of Perlis, the practice will also be rejected and not be taken as state official practice. This subject is to realise the faith that Prophet Muhammad bin Abdillah SAW is the best role model and there is nothing that can compete the greatness of his upheld Sunnah.
\end{abstract}

Keywords: Sunnah Approach, Sunnah Practice, Ahl Al-Sunnah Wa Al-Jamaah, Perlis.

\section{Introduction}

Allah SWT has chosen Muhammad bin Abdillah SAW as a Prophet to descend upon him. After that, he was commanded to explain it to human. Allah SWT said:

Meaning: "And We descended upon you al-Quran, that you may explain to human beings what descended upon you and that they will ponder."

(al-Nahl: 44) 
INTERNATIONAL JOURNAL OF ACADEMIC RESEARCH IN BUSINESS AND SOCIAL SCIENCES Vol. 10, No. 9, 2020, E-ISSN: 2222-6990 @ 2020 HRMARS

There are two explanations meant in this holy verse:

First: Explanation in the meaning of delivering or reciting the words and order of revelation descended upon human without hiding even a letter. This is the commandment contained in words of Allah SWT:

Meaning: "O Messenger, deliver what is descended upon you from your God. And if you do not perform it (what is commanded, that means) you do not deliver His trust. Allah protects you from (disturbance of) human. Truly Allah does not provide guidance to the infidels."

(al-Maidah: 67)

Second: Explanation on meaning of word and meaning of verse required by human. Especially to the words and verses included in mujmal category that needs elaboration, general that needs specification and mutlaq that needs takyid. These all need to be explained by Prophet SAW either through word, action or approval known as al-Sunnah. (al-Albani 1404).

Al-Quran needs al-Sunnah as the explainer and elaborator to the meaning intended by Allah SWT. Without al-Sunnah, al-Quran cannot be understood and is impossible of practice. Thus, alQuran extremely needs al-Sunnah for this intention. This is what meant by scholars' words:

Meaning: "al-Kitab (al-Quran) needs al-Sunnah more than al-Sunnah needs al-Kitab." (Ibn Muflih, 1419)

Perlis is the smallest state in Malaysia, located in the north of Malaysian Peninsula and becomes the only state in Malaysia not bound to any sect. This is states clearly in Constitution of Perlis State Government 1948. The starting point of this establishment is said to begin around year 1920s (Man, 2007) due to influence from Islah wave performed by Islah movement in Egypt by Jamaluddin alAfghani and Muhammad Abduh (Malik \& Mat, 2017). This Islah or Sunnah stream becomes more accepted among the community when it succeeds of influencing several religious figures, state political personnel and royal side. There are three names always mentioned as the main movers of Sunnah or Islah movement in Perlis which are Haji Ahmad b. Haji Muhammad, Dato' Wan Ahmad b. Wan Daud and Dato' Sheikh Ahmad b. Mohd Hashim. The three of them are known in history of Perlis as "Three Mat" (Abdullah, 1997).

Influence of Sunnah movement in Perlis on the strength of evidence and argument has changed several religious practices in Perlis such as Basmalah recitation as Sir, no specific surah Yasin recitation at Friday night, no talkin at cemetery, no arwah feast and others. This difference of practice in the state of Perlis is the fruit of thought that is unbound and not fanatic to any sect. If it is observed, Sunnah approach in Perlis does not only focus on specific ritual practice only, in fact Sunnah approach in Perlis encompasses the whole aspects of Islamic teachings either Faith, Ritual or Financial Transaction which are clearly seen from the fatwas produced. 
INTERNATIONAL JOURNAL OF ACADEMIC RESEARCH IN BUSINESS AND SOCIAL SCIENCES Vol. 10, No. 9, 2020, E-ISSN: 2222-6990 @ 2020 HRMARS

This writing aims to explain the approach of Sunnah practice in Perlis, to elaborate the Sunnah thought in Perlis and to see the extent of efforts have been done and are being done to uphold Sunnah of Prophet SAW at high. There are many writings regarding Sunnah in Perlis done and among them are Mat (2000) al-Sunnah di Perlis, Abdullah (1989) Gerakan Islah di Perlis: Sejarah dan Pemikiran, Din (1976) Syeikh Abu Bakar al-Asyaari: Ulama Tegas Dan Berani, Man (2007) Kedudukan Mazhab Syafi'i Dalam Perkembangan Ahli Sunnah di Negeri Perlis, Malik and Mat (2017) The Historical Development Of The "Sunnah" Reform Ideology In The State Of Perlis, Malaysia, Othman and Baharuddin (1991) Gerakan Pembaharuan Islam: Satu Kajian di Negeri Perlis dan Hubung kaitnya dengan Malaysia and others. However, writings regarding approach of Sunnah practice in Perlis is always fresh for multiplication considering that the Sunnah issue itself remains fresh and is kept on discussed. Due to that, this writing of approach of Sunnah practice in Perlis is done to handle issues of Sunnah generally and in Perlis specifically.

\section{Methodology of Writing}

Methodology implemented in this writing was based on qualitative method. Data were collected from library research and focusing on perception of al-Quran, al-Sunnah, famous books related to sunnah, official documents of Perlis state government and files from Mufti Department of Perlis. Data collected were analysed and elaborated through inductive, deductive and comparative methods to obtain appropriate results complying with the determined objectives.

\section{Findings}

When this discussion is related to sunnah, Then it is a need to explain briefly on the definition of from literal and religious aspect.

Sunnah literally means the path gone through or continuous path either of good or bad (IbnManzur 6/399).

Meanwhile from religious aspect, it means: "word, action and approval of Prophet SAW." (alSyaukani, 1421).

The Companions and al-Salaf when uttering the word Sunnah by mufradah and mu'arrafah word with letter alif and lam without relating it with something then the word refers to Sunnah of Prophet SAW, which is the path meant by Prophet SAW in execution of task bestowed by Allah to him as a guide and explainer of the true religion (Mahdi, 2017).

\section{Royal Speech}

The role of Malay kings as the leader of religion is contained in the constitution of each state related to Islamic religious administration. Each constitution in each state lines the King Ruler of the State as the leader of Islamic religion for the state.

DYMM His Highness King of Perlis, as the State religious leader really concerns on Sunnah approach. His Highness himself for several times has provided explanation on Sunnah approach practised in Perlis. In Multaqa Tuanku Syed Sirajuddin Jamalullail 2018, in Dewan Warisan, Kangar Perlis DYMM His Highness King of Perlis spoke: 
"Public acknowledge that Islamic teaching in Perlis based on method of Ahli Sunah Wal Jamaah, is not bound to any particular figh sect. At the same time, we also appreciate all treasures of Islamic scholars and reject extremism until Islam is regarded as an oldfashioned and difficult religion,"

His Highness also told that, He is confident religious teaching encompassing various views in fiqh of sect under Ahli Sunnah Wal Jamaah by sincere intention and striving towards harmony, will bring development, build civilisation and bring blessings to the whole mankind.

"In coincidence with development of civilisation and modernisation of community, there are various interpretations or ijtihad on a particular practice that can be taken by the ruler or 'Ulil Amri according to socio-culture of a place. In this matter, we are guided by advisory service of Mufti Department and Members of State Fatwa Committee in determination of the best opinion for the community to practise Islamic religion harmoniously without any prejudice or confusion."

\section{Ahl al-Sunnah Wa al-Jamaah in Constitution of Perlis Government}

Constitution of Perlis Government 1948 has bound that method of Ahli Sunnah Waljamaah not binding to any fiqh sect as state's belief. Method of Ahli Sunnah Waljamaah is the main backbone of this constitution. Perlis also becomes one of the earliest states in Malaysia to legalise method of Ahli Sunnah Waljamaah formally and written in the Highest Constitution of State.

In article 5(1) of Constitution of Perlis Government 1948 stating:

"The religion for State is Islamic religion of Ahli Sunah Waljamaah as practised in the State".

To explain on the interpretation for method of Ahli Sunah Waljamaah in Constitution of Perlis State Government 1948, Syariah Committee for Islamic Religion and Malay Customary Council of Perlis (MAIPs) had produced a fatwa gazetting that:

"The meaning of Ahli Sunah Waljamaah is agroup of Muslims holding to al-Quran, al-Sunnah and opinion of the Companions agreeing upon explicit truth from Book of Allah and Sunah of Rasulullah SAW."

This explanation shows that the belief of Perlis state is Ahl al-Sunnah Wa al-Jama'ah not bound to any particular fiqh sect. Any view of fiqh sect is accepted based on authenticity of evidence from alQuran and al-Sunnah brought by the sect."

Continuing from the same fatwa it is stated that:

"The Council is not bound to any particular sect. In any sect, what is clear and explicit from Kitabullah or sunah of Rasulullah SAW or Congregation of Rasulullah SAW's Companions, 
INTERNATIONAL JOURNAL OF ACADEMIC RESEARCH IN BUSINESS AND SOCIAL SCIENCES Vol. 10, No. 9, 2020, E-ISSN: 2222-6990 @ 2020 HRMARS

then the council is ready to accept for its practice. While sects such as Hanafi, Maliki, Syafii and Hambali upon official view of the Council are accounted in famous sects included in the term Ahli Sunah Waljamaah. Islamic Religious Council of Perlis does refer to the sects and take their views that have reason from al-Quran, sunah and Congregation of Rasulullah SAW's Companions."

Therefore, in fiqh knowledge, Perlis Government agree to hold on al-Quran and sunah as the main source of reference, encourage ijtihad in various current issues and reject blind imitation (taklid).

(Nazim \& Hazman, 2018)

\section{Implementation of Sunnah Practice in Perlis State}

Implementation of Sunnah practice in Perlis state is executed in many aspects and not just one aspect. Among them are:

\section{a. Through fatwa}

Fatwas of Perlis state is clearer in stressing the implementation of sunnah practice that becomes the main focus. Some of the fatwas are as follows:

1. Fatwa Regarding Majmuk Syarif Book

After scrutinising the contents of Majmuk al-Syarif book, the meeting unanimously decides as follows:

Majmuk al-Syarif book propagated widely and becoming a source for some community members does contain elements contradicting with faith, false narrations, superstitions and fabricated practices not sourcing from authentic source. Then this book is banned.

2. Fatwa Regarding Status of the Expression al-Madad Ya Rasulullah

The expression al-Madad Ya Rasulullah meaning "Seeking for help O Rasulullah" is a type of al-Istighathah (seek of help) disallowed in Islam as it is a syirik act in prayer based on evidences from al-Quran and al-Sunnah.

3. Fatwa Regarding Claim of Seeing Prophet Consciously

Claim of someone seeing Prophet in consciousness (yaqazah) either in absolute form or spirit after His SAW decease has never been quoted through authentic narration to happen to any Companions RA, even in critical moment, like during the arising of opinion difference among them. That also applies to generation of Tabi'ien and Athba' al-Tabi'ien. Possibility of spiritual yaqazah to happen is a claim doubted and rejected by the muhaqqin such as alNawawi, Ibn Taimiyyah, Ibn Kathir, Ibn Hajar al-'Asqalani, al-Sakhawi, and also al-Qusyairi. That also goes to the claim of seeing Prophet's body in this time consciously which is also rejected. What is narrated from some scholars in this matter is confusing and contradicting in their own statement. The quotes have various differing versions. Some of them claim to see as (heart vision), some claim to see between sleep and consciousness, and some claim with only apparition of Prophet (مثالا له) and many more. All these claims can be interpreted to many which do not necessarily mean yaqazah as understood by some parties. Besides 
that, claim of seeing Prophet in conscious is also exposed to devil's deception. It can open the door of harm with various purposes such as ujub and sum'ah. Therefore any claim of seeing Prophet either in dream or consciousness involving religious implications such as faith belief, religious laws and hadis evaluation is false and deviating. That also goes to the claim that certain incantation can invite Prophet to a certain ceremony which is also of no basis.

4. Fatwa Regarding Deviation of the Term Jihad Fi Sabilillah

The objective of jihad (holy war) in Islam is to uphold and glorify Allah's name. Any action done upon the name of jihad war but poses negative implication to Islam ad its community then it is not a true jihad. By that, action of the groups under jihad's name that has posed negative effect to Islam is not jihad, as it violates the concept and discipline of war in Islam, such as killing those not involved in field of war from among women, elders, children and others. Instead, they commit sin by tarnishing the good name of Islam. Then, joining militant groups such IS and al-Qaedah is not the decreed jihad. A Muslim is prohibited from involving with activity unclear upon the name jihad war, moreover of those that clearly bring harms to Muslim community. What done by IS and al-Qaedah cannot be related to jihad teaching in Islam and it contradicts with al-Salaf al-Soleh's understanding.

5. Fatwa Regarding Environmental Pollution

Islam is a religion preserving human life and nature's benefit. The objective of religion itself is also to uphold benefit and prevent harm. Then, Fatwa Committee of Perlis State by this declare that: Any action of polluting the environment and posing physical harm directly to human, animal and plants is forbidden, excepting existence of greater known benefit or prevention of obvious harm. Every Muslim is obligated to avoid himself from doing any activity and action that can lead to environmental pollution destructing life and disturbing the ecosystem directly. Any effort to protect environment is an action encouraged by religion and becomes a pious deed.

6. Fatwa Regarding Law of Zakat Provision to Non-Muslim Zakat to non-Muslim under Asnaf Muallafah Qulubuhum (the group whose attitude and perception towards Islam are to be harmonized) can be provided upon benefit determined by Ulil Amri. This is like what done by Rasulullah SAW to non-Muslim group among the musyrikin and leaders of tribe as dictated in authentic narrations.

\section{b. Through Brochure and Publication}

Implementation of sunnah practice in Perlis is also executed through published materials distributer for free to Muslim community in Perlis. Among those published material are:

1. Mathur Prayers from Sunnah

2. Fiqh Taysir

3. Fake Hadis and Its Negative Effect to Image of Islam

4. Prayer Guidelines for the Sick

5. Manners of Breaking Fast According to Sunnah 
INTERNATIONAL JOURNAL OF ACADEMIC RESEARCH IN BUSINESS AND SOCIAL SCIENCES Vol. 10, No. 9, 2020, E-ISSN: 2222-6990 @ 2020 HRMARS

6. Compiation of Fatwa Decision 2015-2017

7. Gudelines for Iktikaf of the Last 10 Days of Ramadan

8. Guidelines of Prophet SAW's Prayer Attributes.

9. Compilation of Ramadan Tazkirah

10. Fatwa Regarding Ahbash

11. Custody Right for Parents of Different Religion

12. Guidelines of Prayer in Examination Season

13. Zikir After Solat

14. Compilation of Fatwa Decision of Perlis State Regarding Woman

15. Benefits and Practices in 10 Earliest Days of Zulhijah Month

16. Sunnah and Bid'ah

17. Pamphlet for Campaign of Avoiding Syirik

\section{c. Through Establishment of ISNAD}

Institute of Sunnah and Irsyad (ISNAD) was established officially on 8 May 2005. It is put under supervision and sponsorship of Mufti Department of Perlis State. ISNAD functions as the coordinator for sunnah training and development program to educate community of Perlis State and ensure that understanding of Ahl al-Sunnah Wa al-Jamaah is really strong and fully reflected, that it complies with the need and policy of Islamic Religion and Malay Customary Council of Perlis as dictated in Article 5(1) Constitution of Perlis Government.

The role of ISNAD is different from the role of Mufti Department and Religious Department JAIPs where ISNAD is more of organising training programs based on method of Ahl al-Sunnah Wa alJamaah. Among the programs that have been done and are still going are:

1. Establishment of Center of Sunnah (COS)

Center Of Sunnah is a learning institution of turath books in Islamic studies. It is put under supervision of Institute of Sunnah and Irsyad (ISNAD). Originally, it is the old mosque of Arau, after that renovated in late 2016. It is established to strengthen understanding and inculcate environment of knowledge among community of Perlis State according to method of Ahli Sunnah Wal Jamaah. Its main objective is to produce individuals that can master instrumental knowledge as basic skills needed for understanding of Islamic religion and then are capable of becoming preachers that can deliver knowledge properly.

The study in Center Of Sunnah is performed periodically as daily talaqqi lecture class and periodical program monthly. Official class was begun in February 2017 implementing matan books of basic introduction to Islamic studies. The objectives desired from the study here are:

1. As a platform and centre providing chance for community to peer into religious knowledge systematically

2. Applying talaqqi concept as system of study using suitable matan of turath knowledge.

3. Exposing public to the real discipline of religious knowledge.

4. Producing knowledgeable community whose religious understanding and methodology is strong and are able to disseminate Islamic knowledge with full responsibility. 
INTERNATIONAL JOURNAL OF ACADEMIC RESEARCH IN BUSINESS AND SOCIAL SCIENCES

Vol. 10, No. 9, 2020, E-ISSN: 2222-6990 @ 2020 HRMARS

5. Inculcating understanding of Sunnah of Rasulullah saw's practice and its importance based on scholars' practice in seeking of knowledge as learnt for generations to inherit Sunnah knowledge from Prophet SAW.

Conditions and Advantages of Joining COS Study

1. Open to all Perlis community generally

2. Those who are able of understanding Arabic language well are advantaged to join this study

3. Possesses good attitude and does not have any disciplinary problem and does not smoke.

4. Able to fully commit along commencement of program beginning from early until end of kitab talaqqi.

5. Participants fulfilling attendance of until $80 \%$ will be given certificate of participation for talaqqi study in Centre of Sunnah.

Syllabus of study uses academic matan of Arabic language, among them are:

1. Nahwu.

2. Ulum Hadith.

3. Ulum al-Quran.

4. Usul al-Fiqh.

5. Qawaid Fiqhiyyah.

6. Faraidh.

2. Academy of Imam

A program organised by Mufti Department of Perlis State under supervision of Institute of Sunnah and Irsyad (ISNAD). This program aims to strengthen ability of participants upon mission to prepare apprentice of imam by method of Ahl Al-Sunnah Wal-Jamaah in the future. Among the main visions for establishment of this program is to produce individuals able to bear tasks as imam in daily prayers beginning from family level until are able to be assigned for imam position either in mosques or suraus in Perlis state. This course is organised at four times a year, held for two days which is on Saturday and Sunday. On the first day, participants will be exposed to theoretical course and on the second day they will focus to practical strengthening. Its objectives are:

1. Preparing successing generation of imams for every mosque in the whole Perlis state.

2. Producing imams who hold firmly onto method of Ahl Al-Sunnah Wal Jamaah and practise with sunnah practices.

3. Strenthening self-confidence of participants in delivering sermon and general lecture.

4. Inculcating understanding on Sunnah of Rasulullah saw's practice and its importance according to ritual guidelines that Prophet inherited.

Conditions and Advantages of Joining Academy of Imam

1. Should be of age not less than 16 years until 40 years.

2. Anyone who is able to recite al-Quran well is preferred to join this course.

3. Possesses good attitude and does not have any disciplinary problem and does not smoke 
INTERNATIONAL JOURNAL OF ACADEMIC RESEARCH IN BUSINESS AND SOCIAL SCIENCES Vol. 10, No. 9, 2020, E-ISSN: 2222-6990 @ 2020 HRMARS

4. Able to fully commit along commencement of program beginning from early until end of program.

5. Qualified participants will be considered to fill vacancy of imam position in mosques in Perlis state.

\section{Centre of Corpse Management Darul Abrar (PPJ Darul Abrar)}

Centre of Corpse Management Darul Abrar originally is the old mosque in Kubang Gajah neighbourhood, Arau Perlis. After the new mosque was built next to PPJ Darul Abrar, then this mosque was renovated for corpse management place for Muslim community in the whole Perlis who need its service. It is equipped with two rooms complete for bathing and performing kafan of corpse, an administration room and a lecture hall. In PPJ Darul Abrar, corpse from Asnaf group in Perlis is manages for free. In hall division of PPJ Darul Abrar, training and corpse management course are organised by ISNAD Mufti Department of Perlis based on Sunnah of Prophet Muhammad SAW. Course is held for staffs of Departments of State and Federal Government, private agencies and Muslim community of Perlis as a whole.

\section{Friday ljtimak}

Special weekly program for public community in Perlis state organised by ISNAD, Mufti Department of Perlis State. Aiming to encourage public community in Perlis State of self-strengthening with knowledge regarding tahsin of Quranic recitation, tafsir lecture and lecture of Fiqhus Sunnah kitab by Sayid Sabiq. Lecture begins at 8.30 until 11.00 in Friday morning every week.

\section{Course of Prophet SAW's Prayer Attributes}

Under ISNAD's coordination facilitated by Muballigh of Mufti Department, Course of Prophet SAW's Prayer Attributes is held. It is a periodical program targeting public community in mosques, graduates of Public and Private Higher Learning Institution to provide exposure to participants on the importance of observing the five-time prayers and also authentic practical of prayer ritual based on sunnah of Prophet SAW.

\section{Raudhatul Iktikaf}

Raudhatul Iktikaf program is a program enlivening the last 10 days of Ramadan by doing iktikaf at mosque and academic program is held to ensure that the participants get benefit of knowledge in performing iktikaf ritual. This program which is participated by Sahibus Samahah Dato' Mufti Perlis himself is packed with knowledge slots. During 10 days of the iktikaf, there are four slots of speech, lecture, and tazkirah becoming spiritual meal for the participants which are slot after Tarawih prayer, Subuh lecture, zohor lecture and Asar lecture.

\section{Dakwah Academy of Muslimah}

Under coordination by Institute of Sunnah and Irsyad (ISNAD). This program is of caderisation program, aiming to strengthen ability of participants upon mission to prepare successors among women by method of Ahli Sunnah Wal Jamaah in the future. Among the main visions of this program is to produce individuals able to bear tasks as lecturers sharing knowledge beginning from micro family level until able to be assigned in governmental departments, local universities, mosques and even suraus in Perlis state. This course is held on Saturday and Sunday for 2 days. Its objectives are: 
INTERNATIONAL JOURNAL OF ACADEMIC RESEARCH IN BUSINESS AND SOCIAL SCIENCES Vol. 10, No. 9, 2020, E-ISSN: 2222-6990 @ 2020 HRMARS

1. Preparing successing generation among women in all institutions needing of woman teaching workforce throughout the whole Perlis state.

2. Producing woman teaching workforce firmly holding by method of Ahli Sunnah Wal Jamaah.

3. Strengthening self-confidence of participants in delivering knowledge to community.

4. Polishing participants' skills in solving problems of law regarding woman issue.

5. Inculcating understanding on Sunnah of Rasulullah saw's practice and the importance of following ritual guidelines that He inherited.

Conditions and Advantages of Joining Academy

1. Open to all participants of age 16 to 35 years.

2. Whoever of Islamic studies background possesses a priority of joining this course.

3. Possesses good attitude and does not have disciplinary or crime problem.

4. Able to fully commit along commencement of program beginning from early until end of program.

5. Qualified participants will be considered of filling vacancies for instructors in Mufti Department and Mosque or Surau vacant of woman instructor.

8. Sunnah Village

Sunnah Village Program was introduced in Perlis State for the first time on 8-10 Mei 2015. Program inspired by Mufti of Perlis's idea was organised in conjunction with the $72^{\text {nd }}$ Birthday Anniversary of DYMM His Highness King of Perlis. Alongside with success of organising it for the first time, this Sunnah Village Program has caught the attention of DYMM His Highness King of Perlis declaring that it should be organised at least biannually. Due to that, Sunnah Village was held for $2^{\text {nd }}$ Series on 20 22 November 2015, $3^{\text {rd }}$ on 6-8 May 2016 and $4^{\text {th }}$ on 28-30 April 2017 by maintaining format of content and same location. What changing was the theme of program that becomes the basis of academic discussion in the content of Sunnah Village.

In consequence of that, in year 2018 this program would be continued by the $5^{\text {th }}$ Series. The organisation this time would involve as one of the programs in conjunction with the $76^{\text {th }}$ Birthday Anniversary of DYMM His Highness King of Perlis. In usual, discussion in speech and lecture input slot surrounds on the theme determined in each series. The first was of theme "Sunnah Strengthens Brotherhood", $2^{\text {nd }}$ series was of "Al-Quran Treasure of Knowledge", $3^{\text {rd }}$ series was of "Hadis Source of Knowledge and Civilisation", and 4th series was of "Glory of Mujtahid Imams". While for the $5^{\text {th }}$ series was "Soul Purification According to Sunnah".

The concept of this Sunnah Village is of old-school study (pengajian pondok) in which it serves as an instrument of making Perlis state as a state of knowledge. It centers on study and dissemination of knowledge based on Ahli Sunnah Wal Jamaah's teachings. This sunnah village provides input of knowledge and beneficial activities involving various levels of community. At the same time, it also contributes to strengthening of integrity among Muslim community. The festivity of this program also involves side activity such as exhibition booth, stall, sports event, art events, blood donation and others. 
INTERNATIONAL JOURNAL OF ACADEMIC RESEARCH IN BUSINESS AND SOCIAL SCIENCES Vol. 10, No. 9, 2020, E-ISSN: 2222-6990 @ 2020 HRMARS

\section{Conclusion}

Ahl al-Sunnah wa al-Jamaah is a bounty from Allah SWT as a legacy of Malay community from generation to generation especially in Perlis state. Appearance of several practices violating Sunnah does not deny this relationship. There exist some groups embracing thought and practicing practices contradicting with Sunnah of Prophet SAW, as the thought of blaming laws from rulers even in matters of makruf and for benefit of community. This thought usually comes from religious group of political parties. That also goes to practices among some of sufi extremists and some of public community involved in superstitions. To face these groups, effort of dakwah and Islah have been and keep on performed to ensure that commandment of al-Amr bi al-Ma'ruf wa al-Nahy 'an al-Mungkar is upheld in Perlis. Islah effort in Perlis is stronger mainly after it receives support and endorsement by royal side.

Implementation of sunnah practice has gained great success in Perlis state as it succeeds in getting support from all beginning from royal side, state mufti department until lower citizens. Wrong perception of outer community towards Perlis, such as Perlis rejects scholars and does not have sect, is diminishing by effort of explanation, publication and dialogue organised form time to time especially from state religious administrative side such as Islamic Religion and Malay Customary Council of Perlis (MAIPs), Mufti Department of Perlis and Islamic Religious Department of Perlis (JAIPs).

This writing is more of general exposure. It needs more serious further studies to observe positive and negative effects from every approach of sunnah practice implemented in Perlis. Then, to take benefit and avoid existing weakness to ensure the whole community to remain on Sunnah of Prophet SAW.

\section{Corresponding Author}

Muhamad Abd Kadir bin Sahak. Universiti Islam Malaysia, Cyberjaya, Malaysia.

Email: kadiry2k@gmail.com.

\section{Acknowledgement}

Special thanks to the Majlis Agama Islam Dan Adat Istiadat Melayu Perlis for funding the research under Jamalullail Professorial Chair, Universiti Islam Malaysia.

\section{References}

Al-Albani, M. N. (1404H). Manzilah al-Sunnah Fi al-Islam Wa Bayan Annahu La Yustaghna 'Anha Bi alQuran. Kuwait: Dar al-Salafiyyah.

Ibn Muflih, A. S. D. M. (1419H). al-Adab al-Syar'iyyah. Vol. 2. Beirut: Muassasah al-Risalah.

Saadan, M. (2007). Kedudukan Mazhab Syafi'i Dalam Perkembangan Ahlussunnah di Perlis. Jurnal Fiqh, 4, 141-156

Maszlee, M. K., \& Hamidah, M. (2017). The Historical Development of the "Sunnah" Reform Ideology in the State of Perlis, Malaysia. Jurnal SAGE Open, July-Sept. 1-12

Abdullah, A. R. (1997). Pemikiran Islam di Malaysia: Sejarah dan Aliran. Jakarta, Indonesia: Gema Insani Press.

Mat, S. (2000). al-Sunnah di Perlis. Kangar: Media One Publication. 
INTERNATIONAL JOURNAL OF ACADEMIC RESEARCH IN BUSINESS AND SOCIAL SCIENCES

Vol. 10, No. 9, 2020, E-ISSN: 2222-6990 @ 2020 HRMARS

Abdullah, A. R. (1989). Gerakan Islah di Perlis: Sejarah dan Pemikiran. Kuala Lumpur: Penerbitan Pena Sdn. Bhd.

Din, H. (1976) Syeikh Abu Bakar al-Asyaari: Ulama Tegas dan Berani. Qiblat

Radhzi, M. O., \& Rahmat, D. B. (1991). Gerakan Pembaharuan Islam: Satu Kajian di Negeri Perlis dan Hubung kaitnya dengan Malaysia. Pulau Pinang: Universiti Sains Malaysia.

Ibn al-Manzur, M. M. (n.d). Lisan al-'Arab. Beirut: Dar al-Sadir.

Al-Syaukani, M. A. (1421H). Irsyad al-Fuhul ila Tahqiq al-Haq min 'Ilm al-Usul. Riyadh: Dar al-Fadilah. Al-Qaradhawi, Yusuf bin Abdillah. al-Sunnah wa al-Bid'ah. Kaherah: Maktabah Wahbah.

Khairuldin, W. M. K. F. W., Hassan, S. A., Anas, W. N. I. W. N., Mokhtar, W. K. A. W., \& Embong, A. H. (2020). Al-Takyif Al-Fiqhi and its application in Islamic research methodology. Journal of Critical Reviews, 7(7), 462-467.

Mahdi, A. M. (2017). Ta'rif al-Sunnah bain al-Muhaddithin wa al-Usuliyyin wa al-Fuqaha'. https://www.alukah.net. 29 Nov. 2018.

Hazman, H., \& Nazim, M. N. (2018). Sirajul Muluk: MAlPs di Bawah Naungan Tiga Putera Jamalullail. Malaysia: MAIPs \& DBP 